\title{
Diurnal variations in depth profiles of UV-induced DNA damage and inhibition of bacterioplankton production in tropical coastal waters
}

\author{
Petra M. Visser ${ }^{1,2, *}$, Jan Jaap Poos ${ }^{1}$, Bonnie B. Scheper ${ }^{1}$, Peter Boelen ${ }^{3}$, \\ Fleur C. van Duyl ${ }^{1}$ \\ ${ }^{1}$ Department of Biological Oceanography, Netherlands Institute for Sea Research (NIOZ), PO Box 59, 1790 AB Den Burg, \\ Texel, The Netherlands \\ ${ }^{2}$ Carmabi Foundation Ecological Institute, PO Box 2090, Curaçao, Netherlands Antilles \\ ${ }^{3}$ Department of Marine Biology, University of Groningen, PO Box 14, 9750 AA Haren, The Netherlands
}

\begin{abstract}
In this study, diurnal changes in bacterial production and DNA damage in bacterioplankton (measured as cyclobutane pyrimidine dimers, CPDs) incubated in bags at different depths in tropical coastal waters were investigated. The DNA damage and inhibition of the bacterial production was highest at the surface and decreased with depth. Inhibition of both leucine (Leu) and thymidine (TdR) incorporation was detectable to a depth of $10 \mathrm{~m}$, while DNA damage was measurable only until $5 \mathrm{~m}$. In addition, the decrease of the inhibition of Leu and TdR incorporation with depth was less than the decrease in DNA damage. Variations in DNA damage in bacteria and in biodosimeters were mostly explained by UV radiation (UVR) dose received over time and depth. UVB radiation (UVBR) contributed more than UVA radiation (UVAR) to the damage. The attenuation coefficient of DNA damage with depth was comparable to the attenuation coefficients of UVBR suggesting that DNA damage was induced mainly by UVBR. For incubations at the surface, there was a trend of increasing DNA damage at a constant rate during the entire period of daylight, while the inhibition of leucine incorporation showed a trend of a less rapid increase in the afternoon than in the morning. This might have been due to photorepair, which would also explain the lack of correlation between the inhibition of leucine incorporation and UV dose. It was concluded that CPD damage in DNA is not necessarily the predominant factor in the inhibition of bacterial production. It cannot explain the large impact of sunlight on bacterioplankton productivity in tropical waters.
\end{abstract}

KEY WORDS: DNA damage $\cdot$ Bacterial production $\cdot$ UV radiation Resale or republication not permitted without written consent of the publisher

\section{INTRODUCTION}

Considerable research on the effects of UV radiation (UVR) has been done on the effect of elevated UVR in polar regions produced by ozone depletion, thereby resulting in elevated UVR. In tropical regions, UVR

\footnotetext{
${ }^{*}$ Present address: IBED/Aquatic Microbiology, University of Amsterdam, Nieuwe Achtergracht 127, 1018 WS Amsterdam, The Netherlands.

E-mail: petra.visser@science.uva.nl
}

levels (280 to $400 \mathrm{~nm}$ ) reaching the Earth's surface are several times higher than at higher latitudes (Madronich et al. 1995). Although no trends in ozone changes have been observed at tropical latitudes, the UVR intensities exceed the intensities measured under minimum ozone concentrations at the poles (HolmHansen et al. 1993). The UVR reaching the Earth's surface can be divided in 2 wavelength ranges: UVA radiation (UVAR, 315 to $400 \mathrm{~nm}$ ) and UVB radiation (UVBR, 280 to $315 \mathrm{~nm}$ ). UVBR is more biologically reactive, but is present at low intensity compared to UVAR and photosynthetically active radiation (PAR, 
400 to $700 \mathrm{~nm}$ ). The attenuation of UVR in the water column is a function of wavelength: short wavelength irradiance is more attenuated than longer wavelength irradiance (Kirk 1994, Dunne \& Brown 1996).

Heterotrophic bacteria play a very important role in marine ecosystems because they are responsible for degradation and cycling of organic matter in the sea (Azam et al. 1983). It has been suggested that heterotrophic bacteria are likely to be more susceptible to UV stress than larger organisms, due to their small size and short generation times (Häder et al. 1995) and the absence of UV absorbing pigments (Karentz et al. 1994). Changes in the growth of bacteria upon exposure to UVR have been shown (Thomson et al. 1980, Herndl et al. 1993, Müller-Niklas et al. 1995, Sommaruga et al. 1997). UVR may have both direct and indirect effects on bacterioplankton.

Direct effects involve damage to cellular macromolecules by direct absorption of UVR. UVB radiation causes DNA damage in organisms. The most important consequence of the UVBR absorption by DNA is the formation of photoproducts. Pyrimidine (6-4) pyrimidone and cyclobutane pyrimidine dimers are the most important photoproducts formed (Karentz et al. 1994). The formation of CPDs by UVR in bacterioplankton was shown by Jeffrey et al. (1996a,b), Lyons et al. (1998) and Visser et al. (1999), in the marine diatom Cyclotella sp. by Buma et al. (1997) and in phagotrophic protists by Somaruga \& Buma (2000). The formation of photoproducts disturbs the error-free DNA replication and RNA transcription in cells, which is one of the most important consequences of DNA damage (Karentz et al. 1994). As shown previously, DNA damage (by CPDs) is only caused by UVBR (Buma et al. 1997, Visser et al. 1999). However, inhibition of leucine and thymidine incorporation is also caused by UVAR and PAR (Herndl et al. 1993, Aas et al. 1996, Visser et al. 1999). This suggests that DNA damage is certainly not the only cause of growth inhibition in samples incubated in sunlight, and that there are indirect effects as well.

Indirect effects of UVR can be related to altered bioavailability of dissolved organic matter (DOM) by UVR (Lindell et al. 1995, Herndl 1997, Obernosterer et al. 1999) or to the sensitivity of bacterioplankton grazers to UVR (Sommaruga et al. 1996). Using bioassay experiments, Obernosterer et al. (1999) found that there was no net change in the availability of DOM in the Caribbean Sea off Curaçao after incubation in sunlight. They concluded that most of the DOM in the surface water off Curaçao was already photochemically degraded due to the high irradiation level. UVR can alter DOM in more labile but also more refractory DOM. Therefore, an alternative hypothesis coming from the study of Obernosterer et al. may be that UVR- induced alteration of DOM to both more refractory and more labile DOM was in equilibrium (Kieber et al. 1997, Obernosterer et al. 1999).

In this study, we investigated the direct effects of UVR on bacterioplankton in the surface waters off Curaçao. We do not consider additional indirect effects. We incubated bacterioplankton at different depths to determine the influence of solar radiation on leucine and thymidine incorporation and the formation of CPDs in bacterioplankton in relation with the changing quality and quantity of sunlight in natural waters. Biodosimeters were used to obtain the maximum CPD formation possible (Regan et al. 1992, Boelen et al. 1999). The aims of the study were: (1) to assess the maximum depth at which bacterial production is inhibited and DNA damage is inflicted by surface irradiance; (2) to determine whether changes in bacterial production and DNA damage in depth and time relate to UVR doses received; and (3) to analyze the relationship between bacterial production and CPD formation over diurnal cycles and with depth.

\section{MATERIALS AND METHODS}

Incubations. Field studies were conducted at the Carmabi Institute located at the south coast of Curaçao $\left(12^{\circ} 07^{\prime} \mathrm{N}, 68^{\circ} 57^{\prime} \mathrm{W}\right)$ on $4 \mathrm{~d}$ (4 February, 13 March, 14 and 17 April 1998). The average water temperature at this time was $28.3 \pm 0.5^{\circ} \mathrm{C}$. Hardly any changes in attenuation in the water column occurred in this period. For data on seasonal changes in temperature, nutrients and bacterial production in the coastal waters off Curaçao see Gast et al. 1999. Surface water was sampled at a location (water depth $>100 \mathrm{~m}$ ) $1 \mathrm{~km}$ south of the Carmabi Institute between 08:00 and 09:00 h using an acid-rinsed bucket. The sampled water was immediately transferred to polypropylene bags (5 l) which have high transmission for UV radiation (Visser et al. 1999). These bags were exposed to solar radiation over a coral reef site (depth $15 \mathrm{~m}$ ) attached at fixed depths of 0.1 (submerged), 2, 5 and $10 \mathrm{~m}$, from ca. $09.30 \mathrm{~h}$ onwards until ca. 18:00 h, with bags held in the dark at ca. $1 \mathrm{~m}$ depth. To determine leucine and thymidine incorporation and the formation of CPDs over a diurnal cycle, samples were taken at about 12:00, 15:00 and 18:00 h. For each sample point in time, 5 bags were taken from the water (bags at 0, 2, 5, $10 \mathrm{~m}$ depth and also a darkened bag at each depth), while other bags remained at the fixed depths until the time of sampling. Subsamples from the bag were taken for bacterial production and the rest was used for filtration for analysis of DNA damage. Due to analytical errors, data on DNA damage in biodosimeters on February 4 and on DNA damage in bacterioplankton on April 17 were lost. 
Solar radiation measurements. Profiles of irradiance in the water column were measured at least twice a day. These profiles were performed with an underwater sensor (Biospherical Instruments Model PUV 500) recording $2 \pi$ cosine corrected downwelling irradiance. UVR was measured in narrow bands centered at 305, 320,340 and $380 \mathrm{~nm}$ as well as PAR. The accuracy of the $305 \mathrm{~nm}$ channel sensor is about $10 \%$ (Kirk et al. 1994). The underwater measurements were normalized against the contemporaneous surface record to remove variations that were the results of factors such as changing sun altitude, changes in cloud cover etc. The surface irradiance was measured every $20 \mathrm{~s}$ at the surface during the incubations with a PUV 510 surface sensor. The attenuation coefficient was calculated for every measured wavelength according to LambertBeer's law:

$$
E_{\mathrm{d}}(z)=E_{\mathrm{d}}(0) \mathrm{e}^{-K_{\mathrm{d}} z}
$$

where $E_{\mathrm{d}}(z)$ is the value of downward irradiance at depth $z$ meters, $E_{\mathrm{d}}(0)$ is the value of the downward irradiance just below the surface and $K_{\mathrm{d}}$ is the average value of the downward diffuse attenuation coefficient over the depth interval 0 and $z$ meters. $K_{\mathrm{d}}$ is computed by using the natural logarithm to transform the irradiance data and then deriving the equation of the line using linear regression i.e.:

$$
K_{\mathrm{d}}=-\ln \left[E_{\mathrm{d}}(z) / E_{\mathrm{d}}(0)\right] / z
$$

This approach was also used to calculate the exponential slopes for the data on the inhibition of leucine and thymidine incorporation, DNA damage in bacterioplankton and dosimeters with depth.

The dose at different depths at different wavelengths was estimated by integrating the near continuous data recorded by the surface sensor (PUV 510) and then transforming these for each incubation depth using the derived $K_{\mathrm{d}}$ coefficient.

For estimation of the biologically effective UVR (scalar $4 \pi$ irradiance), biodosimeters were exposed during all experiments to the same irradiance as the incubation bags. Every time bags were sampled, 2 dosimeters were removed and stored in the freezer. Calf thymus DNA in quartz tubes was used for biodosimeters (Boelen et al. 1999). After incubation, the biodosimeters were stored at $-20^{\circ} \mathrm{C}$ until analysis (quantification of thymine dimers in the home laboratory).

Leucine and thymidine incorporation. Leucine and thymidine incorporation was determined as described by Simon \& Azam (1989). Leucine (final concentration $40 \mathrm{nM}_{;} 7.5$ to $10 \%$ leucine $\mathrm{L}-3,4,5-{ }^{3} \mathrm{H}(\mathrm{N})$, specific activity $180 \mathrm{Ci} \mathrm{mmol}^{-1}$ [NEN Life Science Products]) or thymidine (final concentration $10 \mathrm{nM}, 100 \%$ methyl${ }^{3} \mathrm{H}$-thymidine $[\mathrm{NEN}]$, specific activity 84 to $90 \mathrm{mCi}$ $\mathrm{mmol}^{-1}$ ) was added to subsamples of $10 \mathrm{ml}$ in triplicate and a formalin fixed control. The subsamples were incubated for leucine incorporation for 60 to $90 \mathrm{~min}$ and for thymidine 90 to $150 \mathrm{~min}$ in situ in the dark in a floating tray in the water close to the Carmabi pier. Linearity of the incorporation over these incubation times was tested in time series (not shown). Incubation times were kept as short as possible to avoid unintentional enhancement of leucine and thymidine incorporation rates due to confinement effects but long enough to allow accurate determination of bacterial production. The incubation was terminated by adding buffered formaldehyde (1\% final concentration, $\mathrm{pH}$ 7.6). The subsamples were cold extracted on ice for $30 \mathrm{~min}$, and following the addition of TCA to a final concentration of $5 \%$, filtration was performed over $0.2 \mu \mathrm{m}$ filters (Millipore mixed cellulose ester membrane filters) which were subsequently rinsed 4 times with $2 \mathrm{ml} 5 \%$ TCA and twice with $2 \mathrm{ml} 0.2 \mu \mathrm{m}$ filtered seawater with formalin $(2 \%)$. The incorporated ${ }^{3} \mathrm{H}$-leucine and ${ }^{3} \mathrm{H}$ thymidine were determined by liquid scintillation counting (LKB, Rack Beta scintillation counter).

Bacterial counts. Bacteria were enumerated according to the procedure described by Hobbie et al. (1977). Subsamples of $5 \mathrm{ml}$ were stained with acridine orange (final concentration $0.01 \%$ ) and filtered over $0.2 \mu \mathrm{m}$ filters (Millipore, black poly-carbonate). The filters were stored in immersion oil on a glass slide at $-20^{\circ} \mathrm{C}$. The number of bacteria was determined using an epifluorescence microscope (Zeiss axiophot). Typically, 100 to 400 bacteria per slide were counted distributed over 12 to 24 fields. There were no replicate counts.

DNA damage. The water samples were pressurefiltered through series of 10, 0.4 and $0.2 \mu \mathrm{m}$ filters (polycarbonate filters Poretics). The $0.2 \mu \mathrm{m}$ filters were used as the bacterioplankton fraction. Due to filtration over $0.4 \mu \mathrm{m}$ filters not all bacteria were collected in this fraction, but filtration over a higher pore size $(0.8 \mu \mathrm{m})$ resulted in a high amount of phototrophs in the bacterioplankton fraction. After $30 \mathrm{~min}$, the filtration was stopped (about 1.5 to 2.01 were filtered) and the filters were frozen in liquid nitrogen and stored at $-20^{\circ} \mathrm{C}$ until analysis.

DNA isolation and quantification. DNA was extracted from the plankton collected on filters using the modified method of Doyle \& Doyle (1991). The filters were incubated at $60^{\circ} \mathrm{C}$ for $30 \mathrm{~min}$ with $750 \mu \mathrm{l}$ preheated CTAB isolation buffer $(2 \%$ w/v CTAB [Sigma], $1.4 \mathrm{M} \mathrm{NaCl}, 0.2 \%$ v/v 2-mercaptoethanol, $20 \mathrm{mM}$ EDTA, $100 \mathrm{mM}$ Tris-HCl pH 8.0). Then $750 \mu \mathrm{l} \mathrm{CIA}$ (chloroform/isoamylalcohol 24:1) was added to extract the DNA from cell debris. The solution was shaken briefly and subsequently centrifuged in an Eppendorf centrifuge at $14000 \mathrm{rpm}$ for $10 \mathrm{~min}$. The upper (water) phase was transferred to a clean vial and around $0.5 \mathrm{ml}$ ( $2 / 3$ of total volume) cold isopropanol was added to 
precipitate the DNA. This mixture was shaken gently, incubated at $4^{\circ} \mathrm{C}$ for $1 \mathrm{~h}$ and centrifuged subsequently at $4^{\circ} \mathrm{C}$ for $30 \mathrm{~min}$ at $14000 \mathrm{rpm}$. The supernatant was carefully removed and $1 \mathrm{ml}$ of $80 \%$ ice-cold ethanol was added to the precipitated nucleic acids. The vials were placed at $-20^{\circ} \mathrm{C}$ for $15 \mathrm{~min}$ and centrifuged for $30 \mathrm{~min}$ at $14000 \mathrm{rpm}$. The DNA was dried under vac-

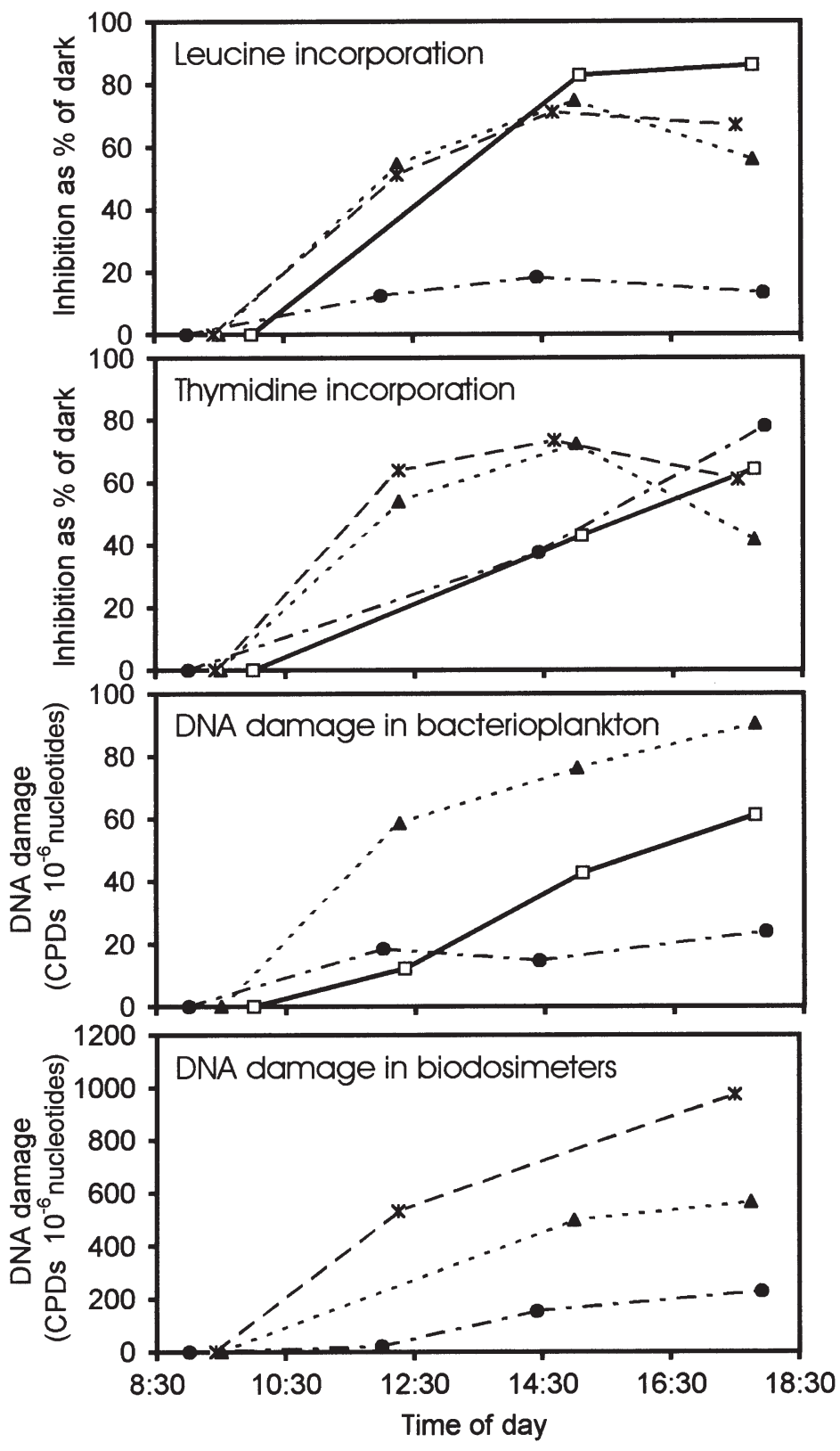

Fig. 1. Diurnal changes in inhibition of leucine and thymidine incorporation as percentage of the dark incubation, and DNA damage (pyrimidine cyclobutane dimers (CPDs) per $10^{6}$ nucleotides) in bacterioplankton $(<0.4 \mu \mathrm{m})$ and biodosimeters after incubation at the surface on 4 sampling days: February 4 (ם), March $13(\boldsymbol{\Delta})$, April $14(\bullet)$ and April $17(\boldsymbol{*})$. Incubations started at around $09.30 \mathrm{~h}$ (first time point) uum and resuspended in $0.1 \times$ TE buffer $(1 \mathrm{mM}$ Tris$\mathrm{HCl} \mathrm{pH}$ 8.0, $0.1 \mathrm{mM}$ EDTA). To remove RNA, the DNA was incubated with $75 \mu \mathrm{ml}^{-1}$ RNase (Boehringer Mannheim) at room temperature for $1 \mathrm{~h}$.

After labeling the DNA with the fluorescent probe Picogreen (Molecular Probes, dilution 1:400) the amount of DNA was determined on a Merlim plate reader (type Titertek Fluoroskan II, Diagnostic Systems, excitation $485 \mathrm{~nm}$, emission $530 \mathrm{~nm}$ ).

CPDs in the DNA extracted from the material either collected on the filters or obtained from the biodosimeters were quantified via an immuno-dot-blot method as described by Boelen et al. (1999). The values of DNA damage (in CPDs on basis of total DNA in the sample) were corrected with the values from the dark incubations.

Statistics. All statistical analyses were done with SYSTAT 7.0 (1997). We applied analysis of variance (ANOVA). With ANOVA the difference of variables (DNA damage, bacterial production) between the light and dark incubations were tested against the independents (sampling date, sampling depth and incubation time). For bacterial production also the difference between light and dark was used, while in the graphs the inhibition was presented. Percentages are mostly used in studies on UV effects on bacterioplankton for presenting inhibition, but the percentages cannot be used in ANOVA tests. The values at the start of the incubation were not used in the ANOVA tests due to a lack of variance. With general linear models (GLM), it was determined whether the bacterial numbers changed during $8.5 \mathrm{~h}$ incubations in bags at $0,2,5$ and $10 \mathrm{~m}$ depth and in the dark. The variation in the natural logarithm transformed ratio of the bacterial abundance at the end and at the start of the incubation were tested against date and water depth.

\section{RESULTS}

DNA damage and bacterial production varied significantly from day to day (Table 1) and with depth. Exposure time had a significant effect only on the DNA damage in biodosimeters.

In Fig. 1, the diurnal changes of inhibition of leucine and thymidine incorporation and of the DNA damage in biodosimeters and in bacterioplankton $(<0.4 \mu \mathrm{m}$ fraction) in the water samples incubated in bags at the surface are shown for 4 different sampling days. In the graphs, inhibition is expressed as percentage of the dark incubation. Absolute values of the incorporation were 12 to $125 \mathrm{pmol}$ leucine $\mathrm{l}^{-1} \mathrm{~h}^{-1}$ and 0.2 to $1.0 \mathrm{pmol}$ thymidine $\mathrm{l}^{-1} \mathrm{~h}^{-1}$. The diurnal changes are different per sampling day. Differences in UV doses of the different days are presented in Table 2 . 
Table 1. ANOVA test of DNA damage (CPDs) in bacterioplankton $(<0.4 \mu \mathrm{m})$ and in biodosimeters and leucine (Leu) and thymidine (TdR) incorporation (dark value is subtracted). ns $=$ not significant, ${ }^{* * *} \mathrm{p}<0.001,{ }^{* *} \mathrm{p}<0.01,{ }^{*} \mathrm{p}<0.05$

\begin{tabular}{|c|c|c|c|c|c|c|c|c|}
\hline \multirow[t]{2}{*}{ Source } & \multicolumn{4}{|c|}{ DNA damage in bacteria } & \multicolumn{4}{|c|}{ DNA damage in biodosimeter } \\
\hline & df & SS & $F$-ratio & $\mathrm{p}$ & df & $\mathrm{SS}$ & F-ratio & $\mathrm{p}$ \\
\hline Date & 2 & 3901 & 12.608 & **** & 2 & 258524 & 6.024 & ** \\
\hline Depth & 3 & 8359 & 18.011 & *** & 3 & 806846 & 12.534 & *** \\
\hline Time & 2 & 177 & 0.572 & ns & 2 & 214877 & 5.007 & ${ }^{*}$ \\
\hline Time $\times$ Depth & 6 & 1561 & 1.682 & ns & 6 & 219351 & 1.704 & ns \\
\hline Error & 20 & 3094 & & & 22 & 472074 & & \\
\hline \multirow[t]{2}{*}{ Source } & \multicolumn{4}{|c|}{ — Leu incorporation —— } & \multicolumn{4}{|c|}{ — TdR incorporation } \\
\hline & df & SS & $F$-ratio & $\mathrm{p}$ & df & SS & F-ratio & $\mathrm{p}$ \\
\hline Date & 3 & 14922 & 19.297 & *** & 3 & 1430 & 30.265 & *** \\
\hline Depth & 3 & 3850 & 4.979 & ** & 3 & 152 & 3.21 & ${ }^{*}$ \\
\hline Time & 2 & 281 & 0.545 & ns & 2 & 46 & 1.458 & ns \\
\hline Time $\times$ Depth & 6 & 988 & 0.639 & ns & 6 & 9 & 0.096 & ns \\
\hline Error & 32 & 8248 & & & 33 & 520 & & \\
\hline
\end{tabular}

incubation period with respect to time and depth (ANOVA, $\mathrm{n}=16, \mathrm{p}>0.05$ ).

Fig. 2 shows that leucine and thymidine incorporation and DNA damage in both bacterioplankton and biodosimeters decreased with depth on some days. While the formation of CPDs was detectable only to $5 \mathrm{~m}$, a clear inhibition of thymidine and leucine incorporation was detectable even at $10 \mathrm{~m}$ depth.

Assuming that changes with depth were caused by light only, the curves of the different variables were fitted with an exponential function (as described in 'Methods'). The calculated exponential slopes (Table 4) of DNA damage in biodosimeters and in bacterioplankton were much higher than of leucine and thymidine incorporation.

Although exposure time had no significant effect (Table 1) on changes in DNA damage in bacteria and bacterial production between 12:00 and 18:00 h, there are certain consistent patterns which evolved during the incubations (Fig. 1). A different trend of diurnal changes was observed for inhibition of bacterial production and DNA damage, but this was not consistent during all days of sampling. A lower inhibition at the end of the day rather than at about 15:00 h was found for leucine incorporation in 3 of $4 \mathrm{~d}$ and for thymidine incorporation in 2 of $4 \mathrm{~d}$. Diurnal changes in DNA damage in both bacterioplankton and biodosimeters showed a different pattern: on all days (i.e. 3, as $1 \mathrm{~d}$ was missing due to analytical errors) DNA damage was higher at the end of the day than in the morning or early afternoon. The damage in biodosimeters was 6 times (March 13) and 10 times (April 14) higher than in the bacterioplankton fraction.

Changes in bacterial production over the incubation period or changes in DNA damage in bacteria cannot be ascribed to changes in bacterial numbers (Table 3). These numbers did not significantly change over the

Table 2. Overview of the doses of UVR received and the CPD-DNA damage obtained in biodosimeters at $0.5 \mathrm{~m}$ during the experiments, which were conducted on the 4 sampling days. nd $=$ not determined

\begin{tabular}{|lccccc|}
\hline & Dimension & \multicolumn{4}{c|}{ 1998 } \\
& & 4 Feb & 13 Mar 14 Apr & 17 Apr \\
\hline UVBR (305 nm) & $\mathrm{mJ} \mathrm{cm}^{-2}$ & 33.4 & 40.4 & 33.2 & 68.9 \\
UVAR (340 nm) & $\mathrm{mJ} \mathrm{cm}^{-2}$ & 830.9 & 987.9 & 820.8 & 1637.0 \\
$\begin{array}{c}\text { DNA damage in } \\
\text { biodosimeter }\end{array}$ & $\begin{array}{c}\text { nd } \times 10^{6} \\
\text { nucleotides }\end{array}$ & nd & 541 & 251 & 1040 \\
\hline
\end{tabular}

In Table 5, the attenuation coefficients are presented for 4 UV wavelengths and PAR. The attenuation coefficient was 0.24 for $305 \mathrm{~nm}$ and less than 0.1 for $380 \mathrm{~nm}$ and PAR with significant differences between the $K_{\mathrm{d}}$ of $305 / 320 \mathrm{~nm}$ and $K_{\mathrm{d}}$ of 340/380 nm/PAR. The slopes of DNA damage in bacterioplankton were not signifi-

Table 3. Numbers of bacteria $\left(\mathrm{n} \times 10^{5} \mathrm{ml}^{-1}\right)$ in unfiltered samples after incubation at different depths at the start $(09: 30 \mathrm{~h})$ and the end of the incubation $(18: 00 \mathrm{~h})$

\begin{tabular}{|rcccc|}
\hline & \multicolumn{4}{c|}{1998} \\
& 4 Feb & 13 March & 14 April & 17 April \\
\hline Start $(09: 30 \mathrm{~h})$ & 3.84 & 1.52 & 2.29 & 1.90 \\
$0 \mathrm{~m}(18: 00 \mathrm{~h})$ & 4.53 & 1.47 & 2.63 & 1.64 \\
$2 \mathrm{~m}(18: 00 \mathrm{~h})$ & 4.42 & 1.29 & - & - \\
$5 \mathrm{~m}(18: 00 \mathrm{~h})$ & 4.93 & 1.07 & - & - \\
$10 \mathrm{~m}(18: 00 \mathrm{~h})$ & 4.51 & 1.64 & 1.92 & 1.65 \\
Dark 1 (18:00 h) & 3.75 & - & 1.73 & 1.82 \\
Dark 2 (18:00 h) & 4.14 & 2.21 & - & - \\
\hline
\end{tabular}

Table 4. Average exponential slopes $\left(\mathrm{m}^{-1}\right)$ (see 'Materials and methods') of DNA damage in biodosimeters (bio) and bacterioplankton (bact) and inhibition of the incorporation rate of leucine and thymidine in sea water incubated with the standard error of the mean (SE) and $r^{2}$. Slope is calculated over values at 4 depths $(0,2,5$ and $10 \mathrm{~m})$. Average taken from slopes at different times (3) and on different sampling days (3 or 4), also see Fig. 2. Number of used slopes is given by $n$

\begin{tabular}{|lcccc|}
\hline & Average slope & SE & $\mathrm{r}^{2}$ & $\mathrm{n}$ \\
\hline DNA bio & 0.371 & 0.046 & 0.812 & 8 \\
DNA bact & 0.236 & 0.013 & 0.937 & 6 \\
Leucine & 0.118 & 0.035 & 0.789 & 8 \\
Thymidine & 0.059 & 0.027 & 0.664 & 8 \\
\hline
\end{tabular}


cantly different from the $K_{\mathrm{d}}$ of $305 \mathrm{~nm}$. The slopes of leucine and thymidine incorporation were not significantly different from the $K_{\mathrm{d}}$ of $380 \mathrm{~nm}$ and PAR. Significance was established whenever there was no overlap in ranges of the coefficients after adding or distracting the SE times 2.

The results of statistic tests performed on the inhibition of incorporation, DNA damage and UVB and UVA doses (see 'Materials and methods') are presented in Table 6. Significant correlations were found between
DNA damage in biodosimeters and bacterioplankton, and the doses of UVB and UVA. Inhibition of thymidine incorporation rate was significantly correlated with UVB and UVA dose, and also with DNA damage in biodosimeters. Inhibition of leucine incorporation was significantly correlated with DNA damage in biodosimeters and bacterioplankton, but not correlated with UV dose. DNA damage in bacterioplankton and inhibition of thymidine incorporation were not significantly correlated.

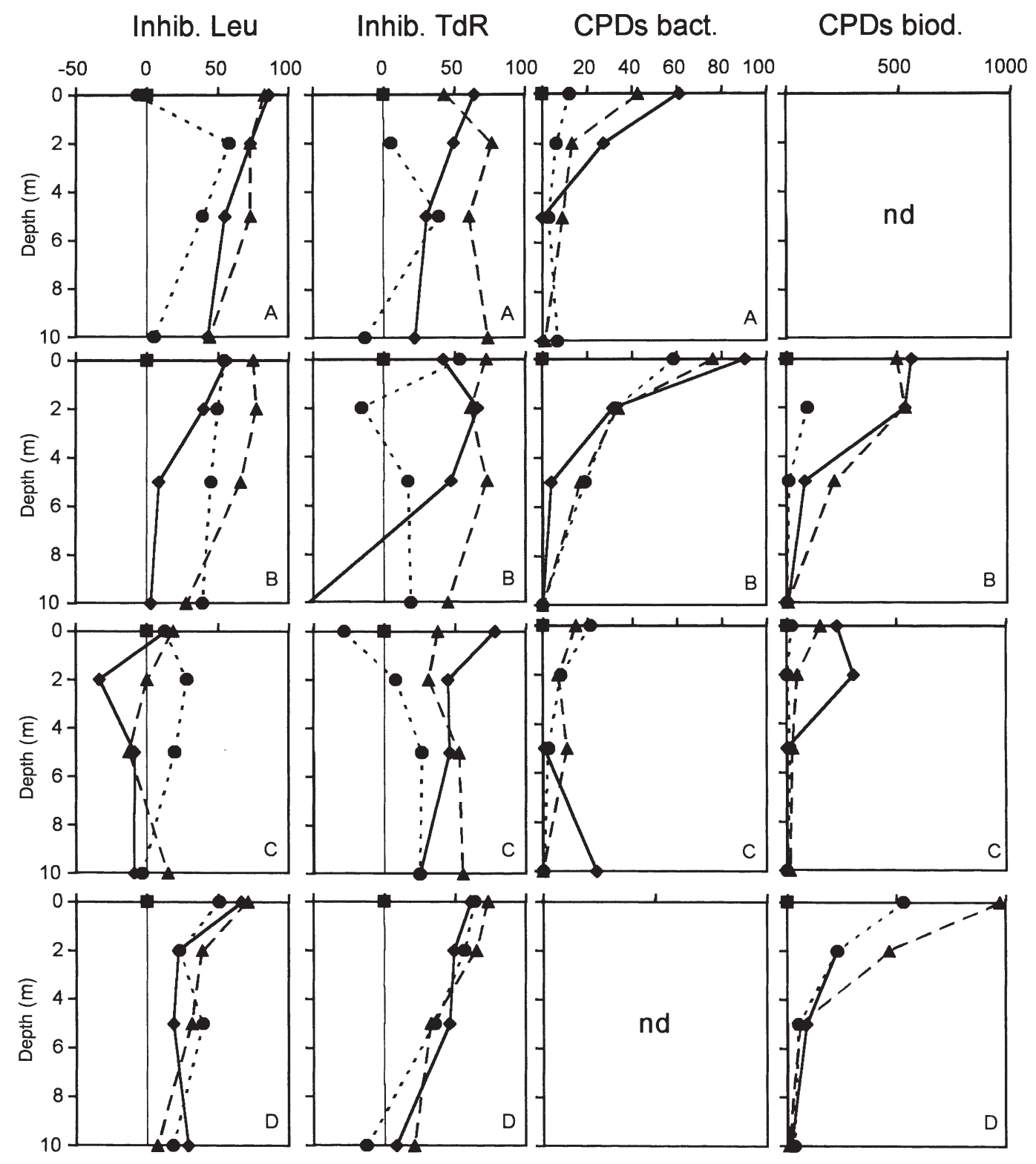

Fig. 2. Depth profiles of inhibition of leucine (Leu) and thymidine (TdR) incorporation as percentage of the dark incubation, and depth profiles of DNA damage (pyrimidine cyclobutane dimers [CPDs] per $10^{6}$ nucleotides) in bacterioplankton $(<0.4 \mu \mathrm{m})$ and

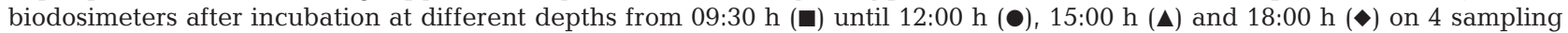
days: February 4 (A), March 13 (B), April 14 (C) and April 17 (D). nd = not determined 
Table 5. Average attenuation coefficients ( $K_{\mathrm{d}}$ values), standard errors (SE, $\mathrm{n}=13$ ) and the depth $(\mathrm{m})$ where the irradiance was $1 \%$ of the surface irradiance at 4 wavelengths of UVR and at PAR (400 to $700 \mathrm{~nm}$ ). The averages are calculated over all depth profiles ( 2 to 4 times $\mathrm{d}^{-1}$ on 4 different sampling days)

\begin{tabular}{|lccccc|}
\hline & $305 \mathrm{~nm}$ & $320 \mathrm{~nm}$ & $340 \mathrm{~nm}$ & $380 \mathrm{~nm}$ & PAR \\
\hline$K_{\mathrm{d}}\left(\mathrm{m}^{-1}\right)$ & 0.240 & 0.202 & 0.139 & 0.075 & 0.093 \\
$\mathrm{SE}$ & 0.020 & 0.021 & 0.017 & 0.013 & 0.010 \\
$\mathrm{r}^{2}$ & 0.976 & 0.956 & 0.896 & 0.699 & 0.764 \\
$1 \%$ depth & 19.2 & 22.8 & 33.1 & 61.3 & 49.3 \\
\hline
\end{tabular}

Table 6. Matrix of Spearman rank correlation coefficients $\left(\mathrm{R}_{\mathrm{s}}\right)$ with significance between inhibition of leucine (Leu) and thymidine (TdR) incorporation, DNA damage (CPDs) in bacterioplankton (bact, $<0.4 \mu \mathrm{m}$ ) and biodosimeters (bio), and the received UV dose (UVB $=305 \mathrm{~nm} ; \mathrm{UVA}=340 \mathrm{~nm})$. Significant correlations shown in bold. $\mathrm{ns}=$ not significant. $\mathrm{n}=$ number of measurements

\begin{tabular}{|cccccc|}
\hline & $\begin{array}{c}\text { UVB } \\
\text { dose }\end{array}$ & $\begin{array}{c}\text { UVA } \\
\text { dose }\end{array}$ & Leu & TdR & $\begin{array}{c}\text { CPDs } \\
\text { (bio) }\end{array}$ \\
\hline Leu & $\begin{array}{c}-0.263 \\
\mathrm{~ns}\end{array}$ & $\begin{array}{c}-0.216 \\
\mathrm{~ns}\end{array}$ & 1 & & \\
& $\mathrm{n}=48$ & $\mathrm{n}=48$ & & & \\
TdR & $\mathbf{- 0 . 6 2 5}$ & $\mathbf{- 0 . 7 0 3}$ & 0.144 & 1 & \\
& $\mathrm{p}<0.01$ & $\mathrm{p}<0.01$ & $\mathrm{~ns}$ & & \\
& $\mathrm{n}=48$ & $\mathrm{n}=48$ & $\mathrm{n}=48$ & & \\
CPDs & $\mathbf{0 . 7 7}$ & $\mathbf{0 . 6 7 9}$ & $\mathbf{- 0 . 5 3 2}$ & $\mathbf{- 0 . 4 9 5}$ & 1 \\
(bio) & $\mathrm{p}<0.01$ & $\mathrm{p}<0.01$ & $\mathrm{p}<0.01$ & $\mathrm{p}<0.01$ & \\
& $\mathrm{n}=36$ & $\mathrm{n}=36$ & $\mathrm{n}=36$ & $\mathrm{n}=36$ & \\
CPDs & $\mathbf{0 . 5 3}$ & $\mathbf{0 . 4 7 3}$ & $\mathbf{- 0 . 2 5 6}$ & -0.213 & 0.742 \\
(bact) & $\mathrm{p}<0.01$ & $\mathrm{p}<0.01$ & $\mathrm{p}<0.01$ & $\mathrm{~ns}$ & $\mathrm{~ns}$ \\
& $\mathrm{n}=34$ & $\mathrm{n}=34$ & $\mathrm{n}=34$ & $\mathrm{n}=34$ & $\mathrm{n}=22$ \\
\hline
\end{tabular}

\section{DISCUSSION}

Our experiments were done in coral reef waters with very low $K_{\mathrm{d}}$ values, some of the deepest recorded UV penetration depths, and yet the induced DNA damage in bacterioplankton was still restricted to the top $5 \mathrm{~m}$ of the water column. The observed $K_{\mathrm{d}}$ values $(0.24$ at $305 \mathrm{~nm}$ and 0.20 at $320 \mathrm{~nm}$ ) were comparable to ocean sites in the Gulf of Mexico, Western Greenland, Red Sea and French Polynesia (Kirk 1994, Dunne \& Brown 1996). DNA damage in bacterioplankton $(<0.4 \mu \mathrm{m})$ induced during the day was found down to only $5 \mathrm{~m}$ depth.

The inhibition of leucine and thymidine incorporation in the bags incubated at fixed depths decreased with depth. This was also found by Aas et al. (1996), Lindell \& Edling (1996), Lyons et al. (1998) and Pakulski et al. (1998). Inhibition can be assumed to be only a result of changes in quantity and quality of the photon flux since this was the only parameter that changed with depth of the incubated samples in our study.

In the profiles of leucine and thymidine incorporation, inhibition was found to reach greater depth than DNA damage in bacteria. In the study of Aas et al. (1996), inhibition of thymidine incorporation was found to a greater depth $(15 \mathrm{~m})$ than DNA damage in biodosimeters (up to $10 \mathrm{~m}$ ). The differences in the profiles of DNA damage and bacterial production were also reflected in the exponents of the equations fitted to the different depth profiles. The exponential slopes for DNA damage in the biodosimeters and in the bacterioplankton were higher than the exponential slopes of the inhibition of production (leucine and thymidine incorporation). Inhibition also caused by UVAR and PAR (with a lower attenuation coefficient than UVBR) might explain this pattern. This is consistent with the results of a former study (Visser et al. 1999), in which DNA damage (CPDs) was found to be caused only by UVBR, while production rates were inhibited by UVBR, UVAR and PAR. In addition, others (Herndl et al. 1993, Aas et al. 1996, Sommaruga et al. 1997) have found that both UVAR and PAR contributed to the inhibition of thymidine and leucine incorporation in bacterioplankton.

The variability in the inhibition and DNA damage in the bacterioplankton between the different sampling days was rather high. ANOVA tests showed most of the variability was from day to day. The variation in doses can also explain some differences, but not all. A very high dose was found on April 17, which was consistent with the high observed inhibition and DNA damage. Also, the low dose on April 14 was consistent with the low inhibition of leucine incorporation and low DNA damage. But the dose on February 4 was not much higher than on April 14, while the inhibition of leucine incorporation was high. Other factors probably also played a role in the changes between the days. Possible causes are changes in bacterial population and the light exposure history of the population due to differences in water masses by mixing or currents (samples were taken from open ocean). Joux et al. (1999) showed wide variations in marine bacteria (in laboratory cultures) in their responses to UV irradiance and subsequent repair strategies. They also demonstrated photoadaptation in bacteria.

DNA damage in the bacterioplankton was 6 to 10 times lower than in the biodosimeters, which might be the effect of a combination of protection of DNA by cell compartments in whole cells compared to bare DNA, repair of DNA damage in living cells and eventual differences in sensitivity of the DNA (e.g. by a different nucleotide composition). From calculations by GarciaPichel (1994), it appeared that small cells have very little protection from cell matter and sunscreen compounds. Our data show that protection by cell compo- 
nents in combination with eventual instantaneous repair of DNA damage can result in much lower DNA damage in bacterioplankton than in bare DNA.

Comparison of diurnal changes in DNA damage and inhibition of bacterial production showed a trend that inhibition of leucine incorporation reached a maximum earlier in the afternoon than DNA damage. In some cases (3 of the 4 sampling days), recovery of leucine incorporation was found at the end of the afternoon. It might be that the cell damage causing inhibition could already be partially repaired in the late afternoon, while this repair was less effective for CPDs. It should be noted here that the determination of CPDs was instantaneous, while the incorporation of leucine and thymidine was determined after incubation in the dark. Another possibility might be that the bacterial production was stimulated by increased extracellular release by phytoplankton due to increased photosynthesis in the late afternoon (Obernosterer \& Herndl 1995, Visser et al. 1999).

Although a trend of a reduced rate of inhibition in late afternoon was found for leucine incorporation, this trend was less obvious for thymidine incorporation. The ongoing induction of DNA damage during the day found in our experiments was not found in previous experiments (Visser et al. 1999) performed under conditions similar to those of this study. Here, the maximum DNA damage in bacterioplankton was reached in the early afternoon and remained constant until the end of the photoperiod. What can be seen from all experiments is that the variability between sampling days is high. However, the inhibition of leucine and thymidine incorporation is apparently not coupled to DNA damage. Even if DNA damage is still high, the incorporation rates can be partly recovered. Also no significant correlations were found between damage in bacterioplankton and inhibition of bacterial production (Table 6).

Significant correlations (Table 6) were found between DNA damage in biodosimeters and UV dose, which could be expected since DNA damage (in the form of CPDs) is the direct consequence of UV radiation. The correlation coefficients between DNA damage in bacterioplankton and UV dose were also significant. A significant correlation was found between inhibition of thymidine incorporation and UV dose, but not for inhibition of leucine incorporation and UV dose. Visser et al. (1999) found a significant correlation between the inhibition of leucine incorporation and UV dose, which was obtained for bacterioplankton incubated at the surface. This study shows that depth in the water column affects this relationship. Repair of damage deeper in the water column (due to a shift to light of longer wavelength which facilitates photorepair) might have influenced the relationships between inhibition and UV dose. This supports the suggestion that photorepair occurred in bacterioplankton incubated deeper in the water column, since photorepair is stimulated under long wavelength irradiance (Kaiser \& Herndl 1997). The higher attenuation at the short wavelengths are selectively removing the damaging UVB at increasing depths whilst leaving the longer wavelengths which are involved in the repair processes. In Huot et al. (2000), photorepair appeared to be important: the calculation of damage at different depths matched the measured values the best when repair (excision repair and photoreactivation repair) was taken into account. The question why photorepair is probably more active with respect to leucine incorporation than thymidine incorporation and DNA damage we cannot answer with our data.

From the results of this and our former study (Visser et al. 1999), it appears that light induced inhibition of the bacterial production might be partly caused by UVBR-induced DNA damage, but also by other factors like damage to enzymes or other cell compounds. As reviewed by Tyrell (1991), UVAR can induce oxidative stress (via generation of active oxygen intermediates) and thereby causes various types of cell damage. Alterations of membranes can be caused by peroxidation of membrane lipids. UVAR-induced DNA damage consists mainly of strand breaks and DNA-protein cross links (Newcomb \& Loeb 1998). It is likely that most enzymes which contain aromatic amino acids will be sensitive to some extent to UVAR, due to absorption in this wavelength region. Inactivations of enzymes, e.g. inhibition of transport of nutrients or amino acids, can be a consequence of UVAR exposure (Fernandez \& Pizarro 1996, Lindell \& Edling 1996). To obtain more insight into all these different UV-induced processes, it is clear that more research is needed.

Acknowledgements. We would like to thank Arjen J. Kop for his assistance and Gerhard J. Herndl for critical reading of the manuscript. We would also like to thank Oscar Franz and Frank Isabella for assistance with sampling. This project was funded by The Netherlands Foundation for the Advancement of Tropical Research (WOTRO grant 84-404). The Biospherical Instruments Model PUV radiometer was provided by an EU grant (MICOR, project number EV5V-CT94-0512 to Gerhard J. Herndl). Richard P. Dunne, Wade H. Jeffrey, Eric Gaidos and 2 anonymous referees are thanked for their many valuable suggestions to this work.

\section{LITERATURE CITED}

Aas P, Lyons MM, Pledger R, Mitchell DL, Jeffrey WH (1996) Inhibition of bacterial activities by solar radiation in nearshore waters and the Gulf of Mexico. Aquat Microb Ecol 11:229-238

Azam F, Fenchel T, Field JG, Gray JS, Meyer-Reil LA, Thingstad F (1983) The ecological role of water-column microbes in the sea. Mar Ecol Prog Ser 10:257-263

Boelen P, Obernosterer I, Vink AA, Buma AGJ (1999) Attenuation of biologically effective UV radiation in tropical 
atlantic waters measured with a biochemical DNA dosimeter. Photochem Photobiol 69(1):34-40

Buma AGJ, Engelen AH, Gieskes WWC (1997) Wavelengthdependent induction of thymine dimers and growth rate reduction in the marine diatom Cyclotella sp. exposed to ultraviolet radiation. Mar Ecol Prog Ser 153:91-97

Doyle JJ, Doyle JL (1991) Isolation of plant DNA from fresh tissue. Focus 12:13-15

Dunne RP, Brown BE (1996) Penetration of solar UVB radiation in shallow tropical waters and its potential biological effects on coral reefs; results from the central Indian Ocean and Andaman Sea. Mar Ecol Prog Ser 144:109-118

Fernandez RO, Pizarro RA (1996) Lethal effect induced in Pseudomonas aeruginosa exposed to ultraviolat-A radiation. Photochem Photobiol 64(2):334-339

Garcia-Pichel F (1994) A model for the internal self-shading in planktonic organisms and its implications for the usefulness of ultraviolet sunscreens. Limnol Oceanogr 39: 1704-1717

Gast GJ, Jonkers PJ, van Duyl FC, Bak RPM (1999) Bacteria, flagellates and nutrients in island fringing coral reef waters: influence of the ocean, the reef and eutrophication. Bull Mar Sci 65(2):523-538

Häder DP, Worrest RC, Kumar HD, Smith RC (1995) Effects of increased solar ultraviolet radiation on aquatic systems. Ambio 24:174-180

Herndl GJ (1997) Role of ultraviolet radiation on bacterioplankton activity. In: Häder DP (ed) The effects of ozone depletion on aquatic ecosystems. RG Landes Company, Austin, TX, p 143-154

Herndl GJ, Müller-Niklas G, Frick J (1993) Major role of ultraviolet-B in controlling bacterioplankton growth in the surface layer of the ocean. Nature 361:717-719

Hobbie JE, Daley RJ, Jasper S (1977) Use of Nucleopore filters for counting bacteria by epifluorescence microscopy. Appl Environ Microbiol 33:1225-1228

Holm-Hansen O, Lubin D, Helbling EW (1993) Ultraviolet radiation and its effects on organisms in aquatic environments. In: Björn EO, Moan J, Nultsch W, Young AR (eds) Environmental UV photobiology. Plenum Press, New York, p 379-425

Huot Y, Jeffrey WH, Davis RF, Cullen JJ (2000) Damage to DNA in bacterioplankton: A model of damage by ultraviolet radiation and its repair as influenced by vertical mixing. Photochem Photobiol 72:62-74

Jeffrey WH, Pledger RJ, Aas P, Hager S, Coffin RB, Von Haven R, Mitchell DL (1996a) Diel and depth profiles of DNA photodamage in bacterioplankton exposed to ambient solar ultraviolet radiation. Mar Ecol Prog Ser 137: 283-291

Jeffrey WH, Aas P, Lyons MM, Coffin RB, Pledger RJ, Mitchell DL (1996b) Ambient solar radiation-induced photodamage in marine bacterioplankton. Photochem Photobiol 64 (3):419-427

Joux F, Jeffrey WH, Lebaron P, Mitchell DL (1999) Marine bacterial isolates display diverse responses to UV-B radiation. Appl Environ Microbiol 65 (9):3820-3827

Kaiser E, Herndl GH (1997) Rapid recovery of marine bacterioplankton activity after inhibition by UV radiation in coastal waters. Appl Environ Microbiol 63:4026-4031

Karentz D, Bothwell ML, Coffin RB, Hanson A and 10 others (1994). Impact of UV-B radiation on pelagic freshwater ecosystems: report of working group on bacteria and phytoplankton. Arch Hydrobiol Beih Ergebn Limnol 43:31-69

Kieber RJ, Hydro LH, Seaton PJ (1997) Photooxidation of triglycerides and fatty acids in seawater: implication toward the formation of marine humic substances. Limnol Oceanogr 42:1454-1462

Kirk JTO (1994) Optics of UV-B radiation in natural waters. Arch Hydrobiol Beih Ergebn Limnol 43:1-16

Kirk JTO, Hargreaves BR, Morris DP, Coffin RB and 9 others (1994) Measurements of UV-B radiation in two freshwater lakes: an instrument intercomparison. Arch Hydrobiol Beih Ergebn Limnol 43:71-99

Lindell M, Edling H (1996) Influence of light on bacterioplankton in a tropical lake. Hydrobiologia 323:67-73

Lindell MJ, Graneli W, Tranvik LJ (1995) Enhanced bacterial growth in response to photochemical transformation of dissolved organic matter. Limnol Oceanogr 40(1):195-199

Lyons MM, Aas P, Pakulski JD, Van Wasbergen L, Miller RV, Mitchell DL, Jeffrey WH (1998) DNA damage induced by ultraviolet radiation in coral-reef microbial communities. Mar Biol 130:537-543

Madronich S, McKenzie RL, Caldwell MM, Bjorn LO (1995) Changes in ultraviolet radiation reaching Earth's Surface. Ambio 24:143-152

Müller-Niklas G, Heissenberger A, Puskaric S, Herndl GJ (1995) Ultraviolet-B radiation and bacterial metabolism in coastal waters. Aquat Microb Ecol 9:111-116

Newcomb TG, Loeb LA (1998) Oxidative DNA damage and mutagenesis. In: Nickoloff JA, Hoekstra MF (eds) DNA damage and repair, Vol 1: DNA Repair in prokaryotes and lower eukaryotes. Humana Press Inc., Totowa, p 1-8

Obernosterer I, Herndl GJ (1995) Phytoplankton extracellular release and bacterial growth: Dependence on the inorganic N:P ratio. Mar Ecol Progr Ser 116(1-3):247-257

Obernosterer I, Reitner B, Herndl GJ (1999) Contrasting effects of solar radiation on dissolved organic matter and its bioavailability to marine bacterioplankton. Limnol Oceanogr 44(7):1645-1654

Pakulski JD, Aas P, Jeffrey W, Lyons M, Von Waasenbergen L, Mitchell D, Coffin R (1998) Influence of light on bacterioplankton production and respiration in a subtropical coral reef. Aquat Microb Ecol 14:137-148

Regan JD, Carrier WL, Gucinski H, Olla BL, Yoshida H, Fujimura RK, Wicklund RI (1992) DNA as solar dosimeter in the ocean. Photochem Photobiol 56:35-42

Simon M, Azam F (1989) Protein content and protein synthesis rates of planktonic marine bacteria. Mar Ecol Progr Ser 51:201-213

Sommaruga R, Buma AGJ (2000) UV-induced cell damage is species-specific among aquatic phagotrophic protists. J Eukaryot Microbiol 47:450-455

Sommaruga R, Oberleiter A, Psenner R (1996) Effect of UV radiation on the bacterivory of a heterotrophic nanoflagellate. Appl Environ Microbiol 62(12):4395-4400

Sommaruga R, Obernosterer I, Herndl GJ, Psenner R (1997) Inhibitory effect of solar radiation on thymidine and leucine incorporation by freshwater and marine bacterioplankton. Appl Environ Microbiol 63(11):4178-4184

Thomson BE, Van Dyke H, Worrest RC (1980) Impact of UV-B radiation (290-320 nm) upon estuarine bacteria. Oecologia (Berl) 47:56-60

Tyrell RM (1991) UVA (320-380) radiation as an oxidative stress In: Sies H (ed) Oxidative stress: oxidants and antioxidants. Academic Press, London p 57-83

Visser PM, Snelder E, Kop A J, Boelen P, Buma AGJ, van Duyl FC (1999) Effects of UV radiation on DNA damage and production in bacterioplankton in the coastal Caribbean Sea. Aquat Microb Ecol 20 (1):49-58

Submitted: December 20, 1999, Accepted: July 26, 2001 Proofs received from author(s): February 12, 2002 